\title{
Finance-oriented directors and crisis management: Blissful ignorance in the hospitality industry?
}

\author{
Anthony L. Iaquinto ${ }^{\mathrm{a},}{ }^{*}$, Vivien Jannicelle ${ }^{\mathrm{b}}$, Wayne G. Macpherson ${ }^{\mathrm{c}}$ \\ a Cleveland State University, Monte Ahuja College of Business, BU436, 2121 Euclid Ave, Cleveland, OH 44115, United States \\ b Texas A\&M University Central, Killeen, TX 76549, United States \\ ${ }^{\text {c } M a s s e y ~ B u s i n e s s ~ S c h o o l, ~ M a s s e y ~ U n i v e r s i t y, ~ P a l m e r s t o n ~ N o r t h, ~ 4474, ~ N e w ~ Z e a l a n d ~}$
}

\section{A R T I C L E I N F O}

\section{Article history:}

Received 25 September 2016

Received in revised form

27 March 2017

Accepted 28 April 2017

\section{Keywords:}

Crisis management

Upper echelons

Finance-oriented directors

Blissful ignorance

\begin{abstract}
A B S T R A C T
The primary purpose of this study was to examine the demographic characteristics of Boards of Directors in the hospitality industry, and how those characteristics can impact a firm's performance during a major crisis. More specifically, using the upper echelons perspective, this study examined the impact of financeoriented directors, and directors who were outsiders, on a company's stock price during the great recession. Results using companies from the hospitality industry indicate that companies that had the highest percentage of finance-orientated directors tended to fall further and recover less quickly. Yet, in the aftermath of the crisis, companies that performed worse during the crisis tended to increase the percentage of finance-oriented directors. The authors of the study assert that extending the application of the blissful ignorance effect is a logical explanation for the behavior found in the results.
\end{abstract}

(c) 2017 The Authors.

\section{Introduction}

How an organization performs during changes in its external environment can be critical to its success (Cho \& Hambrick, 2006; Hambrick, 2007; Ocasio, 1997). This can be particularly true when companies experience a crisis (Goldberg \& Petasnick, 2010). In the hospitality sector, for example, potential crises include: outbreaks of food-borne illnesses, rodent infestations, equipment breakdowns and supply disruptions. Perhaps most calamitous is when whole industries, or whole economies, are hit with a wide-spread crisis, such as a natural disaster or an economic collapse, that is defined as a high-impact event that threatens the organization's viability and is characterized by ambiguity of cause and effect (Brandstrum, Bynander, \& Hart, 2004; Pearson \& Clair, 1998). Though wide-spread crises occur somewhat infrequently, they do present opportunities to examine how differing organizations perform while facing a similar scenario. As such, research on these larger events could shed light on how organizations perform during more local disasters.

Inspired by a framework for crisis management by Smits and Ezzat (2003), which was itself influenced by the upper echelons

\footnotetext{
* Corresponding author.

E-mail address: a.iaquinto@csuohio.edu (A.L. Iaquinto).
}

perspective (Hambrick \& Mason, 1984), the primary purpose of this paper was to examine the impact of finance-oriented directors on a company's ability to successfully manage a major crisis. Post hoc tests were then used to explore any significant changes in the percentage of finance-oriented individuals on the BODs during a major crisis. Finally, the author(s) of this study assert that the combination of the results from the primary, and ad hoc analysis, are best explained by extending the managerial application of the concept called "blissful ignorance".

\section{Literature and hypotheses}

In 2003, Stanley Smits and Niveen Ezzat presented a framework for crisis management that argues that firm performance during a crisis event is the responsibility of organizational leadership; that a firm's response to a major change in their environment is shaped by the ability of organizational leadership to adequately process information in a timely manner (Ocasio, 1997; Smits \& Ezzat, 2003). And while many actors within an organization may play a role in environmental scanning, much of the data gathering and interpretive work is assumed to be done by the organization's leadership (Cho \& Hambrick, 2006). In turn, the ability of an organization's leadership to effectively and efficiently respond to information is dependent, at least in part, by the characteristics of that team-the upper echelon perspective (Hambrick \& Mason, 
1984; Hambrick, 2007).

Significant evidence exists to support purported links between the demographic characteristics of the organization's leadership and organizational actions (Hambrick, 2007; Nielsen, 2010a; Adams et al., 2015). For example, studies have found significant relationships between the demographic makeup of an organization's leadership and a company's proclivity to discuss entrepreneurial issues (Tuggle, Schnatterly, \& Johnson, 2010), its inclination to internationalize (Rivas, 2012; Hsu, Chen, \& Cheng, 2013), and their bent to focus on innovation (Talkea, Salomob, \& Rost, 2010). Further studies have successfully linked demographic characteristics to a firm's voluntary financial disclosure choices (Bamber, Jiang, \& Wang, 2010), the comprehensiveness of a firm's strategic decision-making process (Fredrickson \& Iaquinto, 1989) and the makeup of an organization's strategy (e.g., Geletkanycz \& Hambrick, 1997; Alexiev, Jansen, Van den Bosch, \& Volberda, 2010).

However, as for a direct link between the demographic characteristics of a firm's leadership and firm performance, there is mostly conflicting evidence (Nielsen, 2010b; Adams et al., 2015). As such, there remains a need for further tests of the link between demographic characteristics and firm performance.

Since the publication of the seminal paper on the Upper Echelon perspective (Hambrick \& Mason, 1984) the demographic characteristic that appears to have garnered the most attention is diversity, this includes several reviews, at least one meta-analysis and numerous papers (Adams et al., 2015; Homberg \& Hong, 2013; Nielsen \& Nielsen, 2013; Nielsen, 2010a; Talkea et al., 2010). Emulating the general links between leadership characteristics and firm performance, there is a lack of consensus among studies that have examined the specific link between leadership diversity and firm performance.

On one hand greater diversity should make it more likely that leadership will become aware of new stimuli and to include it in relevant discussions, thus leading to better performance (Hambrick \& Mason, 1984; Hambrick, 2007). And results of one recent study, Ferrero-Ferrero et al. (2015) showed that greater age diversity can lead to more effective visions and strategies, which in turn leads to a greater adoption of more effective corporate governance codes. In another study, Terjesen, Couto, and Francisco (2016) found that gender diversity directly leads to higher firm performance.

On the other hand, greater leadership diversity could increase social friction and discourage social integration, which could negatively impact the efficiency of the decision-making process, leading to larger hits on the bottom line (Adams et al., 2015; Ferrero-Ferrero et al., 2015; Li, 2013; Smith et al., 1994). In sum, past tests on the relationship between diversity and firm performance have found negative effects (Murray, 1989), no effects (Homberg \& Hong, 2013; Michel \& Hambrick, 1992; Nielsen, 2010a) and positive effects (Eisenhardt \& Schoonhoven, 1990) Therefore, further studies are needed to establish which of the three scenarios is most valid.

Given the lack of concrete guidance from either the theoretical or the empirical realm, the author(s) of this study crafted a set of hypotheses using the assumption that there is a positive relationship between leadership diversity and firm performance during a crisis event. Support for such a perspective can be found in a paper from Talkea et al. (2010) and others, who convincingly argued that demographics characteristics of the Board of Directors, specifically diversity, can among other things, enhance firm performance by facilitating innovation, which in turn, generates new ideas that could help companies weather a widespread economic crisis (Chavan, 2005; Smart \& Vertinsky, 1984; Zack, 1999). Therefore, the author(s) of this study argues that TMT diversity can have a strong positive impact on choices made, which in term leads to better firm performance.
This leads to two sets of hypotheses:

Hypothesis 1a. During a major economic crisis, firms having a higher percentage of outsiders on the BODs will fall less than firms having a lower percentage of outsiders on the BODs.

Hypothesis 1b. During a major economic crisis, firms having a lower percentage of individuals with a finance orientation on the BODs will fall less than firms having a higher percentage of individuals with a finance orientation.

Hypothesis 2a. During a major economic crisis, firms having a higher percentage of outsiders on the BODs will have a better recovery than firms having a lower percentage of outsiders on the BODs.

Hypothesis 2b. During a major economic crisis, firms having a lower percentage of individuals with a finance orientation on the BODs will have a better recovery than firms having a higher percentage of individuals with a finance orientation.

\section{Method}

\subsection{Sample}

The author(s) identified 81 hospitality companies listed on either the NYSE or the NASDAQ exchange. The author(s) of this study elected to use the hospitality industry because unlike industries such as manufacturing, the hospitality industry is crisis prone and vulnerable to numerous external pressures (Ritchie, 2004).

\subsection{Data sources}

All primary and post hoc data was gathered through the use of DEF 14As and 10Ks using the Edgar company filings website of the SEC; and Yahoo Finance.

\subsection{Timeframe}

This study explored the link between BOD diversity and firm performance during the Great Recession. The U.S. National Bureau of Economic Research declared that the 'Great Recession' started on December of 2007 and ended on June, 2009. Therefore, this study used December 1, 2007 as the starting point for this study and June 30,2009 as the end point of this study.

\subsection{Dependent variables}

Given the relative paucity of empirical investigations on the determinants of firm performance during a crisis, widely accepted constructs for measuring performance during a major crisis do not exist. However, the work done by Smits and Ezzat (2003) suggests that the extent of a firm's fall and the extent of a company's recovery could be two reasonable metrics.

To determine the extent of a firm's fall and the extent of a company's recovery, the author(s) first utilized Yahoo Finance's Interactive Stock Chart to tract the Dow Jones Index from December 1, 2007 to June 30, 2009. During the 18 months of the Great Recession, the Dow Jones composite hit its nadir on March, 9th of 2009. Not surprisingly, the movements of the individual stocks used in this study have similar V configurations, with $80 \%$ of the individual stocks used in this study hitting their nadir 30 days within the ninth of March of 2009.

Therefore, the author(s) used the stock price on the day each company hit its nadir to calculate both the extent of a company's 
fall and the extent of a company's recovery. More specifically, the author(s) calculated the extent of a firm's fall by subtracting the stock price at that company's nadir by the stock price on December 1, 2007 (the start the Great Recession), and dividing that by the stock price on December 1, 2007, to get the percentage change as the measure of the extent of a stock's fall. Similarly, the author(s) calculated the extent of a firm's recovery by subtracting the stock price on June 30, 2009 (the end the Great Recession) by the stock price of the company's nadir and dividing that by the stock price on the company's nadir to get the percentage change as the measure of the extent of a stock's recovery.

It was the author(s) judgement that changes in individual stock prices were an appropriate measure of organizational performance during a crisis. First, stock prices possess attributes such as objectivity and understandability, which are required of acceptable performance measures (Merchant \& Bruns, 1986). Further, in a study of 241 firms, Lehn and Makhija (1996) found that stock prices were highly correlated with economic value added (EVA) and market value added (MVA), arguing that stock prices are effective and relevant metrics.

Using stock prices, as opposed to accounting figures, would also allow analysis with dependent variables that were more readily aligned with the timing of the crisis event. In addition, since the economic crisis in question was reflected by a severe drop in stock prices, using company stock prices as dependent variables seemed a logical fit. Finally, by using individual stock prices as the dependent variable, this study assumed it would be capturing the reactions of individual market participants based on their perceptions of how well individual companies are performing during a crisis. In essence, market participants will be looking for any signs that specific companies are effectively and efficiently responding to the current situation (Pandelica \& Pandelica, 2009, pp. 311-324).

This assumption seems reasonable given work on signal theory (Spence, 1973) which other streams of research have co-opted (Karasek \& Bryant, 2012). For example, Marcus and Goodman (1991) found that signals can serve the interest of shareholders during a crisis and one recent study examining the New York Stock Exchange found that market participants re-adjusted their precrisis expectations of returns to companies that had received higher corporate social responsibility ratings (Becchettie, Ceniccola, \& Ciciretti, 2010, pp. 1-42). And in a related study, Higgins and Gulati (2005) discovered that attributes of organization's leadership can impact investors' decisions. Therefore, it seems reasonable to conclude that market reactions are important, if for no other reasons to attract resources; which could be particularly vital during a crisis.

\subsection{Independent variables}

In prior tests of the diversity performance link researchers have used a variety of measures, such as age, tenure, gender, race and education (Adams et al., 2015; Nielsen, 2010a). However, logic and precedent (Brochet \& Welch, 2011) lead the author(s) to employ the two measures that seem most appropriate for predicting performance differences during a major economic crisis: the percentage of outside directors, and the percentage of finance-oriented individuals on the BODs.

\subsubsection{Percentage of outsiders on the BOD}

This variable was derived by dividing the number of the outsiders on the BOD by the BOD size (the number of board members). The author(s) selected to use Board of Directors (BODs), rather than Top Management Teams (TMTs), because at least one prior study noted that when all other variables were equal, diversity in the
BODs made a significant impact on firm performance, while the diversity in the TMTs did not make any difference to firm performance (Marimuthu \& Kolandaisamy, 2009).

\subsubsection{Percentage of individuals with a finance orientation}

This variable was calculated by dividing the number of individuals with a finance orientation on the BOD by the BOD size. Our definition of "finance-oriented individuals" is anyone on the BODs who were describe in their biography (in the DEF 10-A) as having significant experience as a Treasurer, Chief Financial Officer, Controller, or a partner of a finance company OR who were describe in the DEF 10-A as having an "expertise in finance". This follows a similar method used by Brochet and Welch (2011).

\subsection{Control variables}

Organizational performance is often constrained by a variety of factors, such organizational age, size and past performance (Hannan \& Freeman, 1984). Therefore, four control variables were included in the model: company age (years since founding); company size (total sales prior to each time period in question); $B O D$ Size (determined by the total number of members on the BOD) and past performance. For the analysis of the extent of the fall, the percentage change in stock prices during the 18 -month period prior to the start of the Great Recession was used as the measure for past performance. It seemed logical to calculate past performance as a 18 month period given that the Great Recession lasted 18 months. As for equations testing the extent of recovery, the author(s) use the Extent of the fall as the measure of past performance.

\section{Results}

\subsection{Primary results}

Table 2 provides the relationships among the dependent, independent and control variables. Correlation analysis reveals a significant negative relationship between the percentage of financeoriented individuals on the BODs and the extent of a stock's fall, suggesting that firms having a lower percentage of financeoriented board members will fall less during a major economic crisis, which would support hypothesis $1 \mathrm{~b}$. Unfortunately, there were no other significant relationships that support or refute any of the other hypotheses. However, the author(s) did find significant relationships between three of the four control variables (company age, company size, and BOD size). While these relationships were not predicted, the results are not unexpected. Finally, there is a significant negative relationship between the extent of a company's fall and the extent of a company's recovery, which may suggest that companies that fell the most had the better recoveries.

In further tests of the hypotheses, the author(s) utilized multiple regression analysis. Column I of Table 3 indicates that after controlling for firm age, firm size, BOD size and past performance, two independent variables have significant coefficients. First, there is a positive relationship between the percentage of outsiders and the extent of a stock's fall. In other words, during a major crisis, firms with larger percentages of outsiders fell less than firms with smaller percentage of outsiders. This result supports hypothesis 1 a.

Second, the percentage of finance-oriented individuals on the BOD is significantly and negatively associated with the extent of a stock's fall, meaning that the stock prices of firms with a higher percentage of finance-oriented individuals on the BODs fell further during an economic crisis than companies with a lower percentage. This finding supports hypothesis $1 \mathrm{~b}$.

Looking at column II in Table 3, there seems to be a relatively 
strong negative relationship between the percentage of financeoriented individuals on the BOD and the extent of a stock's recovery, which supports hypothesis $2 \mathrm{~b}$, which stated that during a crisis, firms having a higher percentage of individuals with a finance orientation on the BOD will recover more poorly than firms having lower percentage of individuals with a finance orientation. Finally, there is a very significant negative relationship between the extent of the fall of a company's stock price and the extent of the recovery of a company's stock price.

\subsection{Post hoc results}

Given the relatively strong findings that a greater percentage of finance-oriented individuals on the BOD seems to lead to weaker stock performance during a time of a crisis, the author(s) decided to explore whether there were any changes in the percentage of individuals with a finance orientation on BODs after the crisis had abated. ${ }^{1}$ Looking back to Table 1 , the average percentage of individuals with a finance orientation on BODs in 2008 was $36 \%$. After collecting post hoc data from the same sources used to collect the primary data, the authors discovered that the average percentage of individuals with a finance orientation on the BODs five years later was $44 \%$ (a $t$-test found the difference was significant at the $\mathrm{p}<0.01$ level). The outcome suggests that although higher percentages of finance oriented individuals on the BODs seem to have a detrimental impact on company's stock performance, these same companies decided to increase the percentage of finance-oriented directors on their BODs in the aftermath of the crisis.

Further analysis (Table 4) presents the results of a multiple regression using change in the percent of the individuals with a finance orientation on BODs as the dependent variable. There are two significant relationships. First, there is a strong negative relationship between the percentage of finance-oriented individuals on the BODs in 2008 and the percentage change in the percentage of finance-oriented individuals on the BODs. In other words, companies with BODs that had the fewest percentage of individuals with a finance orientation on the BOD in 2008, added the greatest percentage of finance-oriented directors five years later. In addition, there is a relatively strong and negative relationship between the percentage change in the BOD size and the percentage change in the percentage of finance oriented individuals on the BODs. Translation: among hospitality companies, as BOD size decreased, the percentage change in the percentage of finance oriented individuals on the BODs increased, which means that companies reduced the percentage of non-finance oriented individuals rather than the percentage of finance-oriented individuals.

\section{Discussion}

\subsection{Primary discussion}

A review of prior literature led to two sets of hypotheses linking diversity in the BODs (the percentage of outsiders and the percentage of individuals with a finance orientation) and firm performance (the extent of the fall of a company's stock price and the extent of the recovery of a company's stock price) during a major economic crisis.

The two most significant findings are: the strong negative relationship between the percentage of individuals with a finance orientation and the extent of the fall of a firm's stock price, and the strong negative relationship between the percentage of individuals

\footnotetext{
${ }^{1}$ Similar Post Hoc tests were performed using the percentage of outsiders. No significant results were found.
}

Table 1

Descriptive statistics.

\begin{tabular}{lllll}
\hline & Minimum & Maximum & Mean & Std. Deviation \\
\hline Company Age & 2 & 96 & 36.48 & 21.862 \\
Company Size & 8 & 34,290 & 2068 & 4709 \\
BOD Size & 4 & 15 & 8.31 & 2.08 \\
BOD \% Outsiders & 0.44 & 1 & 0.75 & 0.11 \\
BOD \% Finance & 0 & 0.86 & 0.36 & 0.2137 \\
Past Performance & -5.85 & 0.9 & -0.09 & 0.83 \\
Extent of Fall & -0.98 & 0.23 & -0.65 & 0.22 \\
Extent of recovery & 0.01 & 3.37 & 1.04 & 0.76 \\
\hline
\end{tabular}

$\mathrm{N}=81$.

with a finance orientation and the extent of a the recovery of a firm's stock price, which support hypotheses $1 \mathrm{~B}$ and $2 \mathrm{~B}$ respectively. These results are similar to the work by Minton et al. (2011) who found that during the great recession, financial expertise among independent directors of financial institutions were negatively associated to changes in both Tobin's Q and cumulative stock returns. And in a more general sense, this study supports other recent studies that found significant direct relationships between the demographic characteristics of organizational leadership and firm performance (Colbert, Barrick, \& Bradley, 2014; Eesley, Hsu, \& Roberts, 2014; Huang, 2013; Post \& Byron, 2015; Terjesen et al., 2016), thus further solidifying one of the main tenets of the upper-echelons perspective, that demographic characteristics of organizational leadership can accurately predict firm performance (Hambrick \& Mason, 1984; Hambrick, 2007). At the same time, these outcomes provide credibility to Smits and Ezzat's (2003) framework for crisis management, which argues that firm performance during a crisis is at least partially determined by the demographic characteristics of a company's organizational leadership.

Although this study revealed a strong connection between the percentage of finance-oriented individuals on the BODs and firm performance during a major crisis, the findings do not completely explain the whole story. As such, it is worthwhile to consider possible behavioral attributes that might better explain the results. For instance, literature exists that argues that individuals with a finance orientation, such as CFOs, tend to be more conservative than other members of an organization's leadership, especially in such decisions as: investment policies, financing policies, budgeting and internal control (Goodman, O'Brien, \& Segal, 2000; Chava \& Purnanandam, 2010; Lawson \& Omer, 2012). Another line of literature suggests, and evidence supports, that companies should be aggressive during a crisis in order to increase firm performance (Chavan, 2005; Smart \& Vertinsky, 1984; Zack, 1999). Therefore, in a crisis, if any of the company's stakeholders presented a plan that included actions that were 'appropriate', but financially aggressive, they would probably face stiff resistance, if not upright rejection, from the more conservative finance-oriented directors.

\subsection{Post hoc discussion - blissful ignorance}

The primary results supported the hypotheses that a greater percentage of finance-oriented individuals on the BODs are associated with inferior performance during a time of a major crisis as measured by a company's stock price. Post hoc tests on the structure of the BODs five years after the crisis found a significant increase in the percentage of finance-oriented individuals on the BODs, most likely by either shrinking the board via jettison individuals who did not have a finance orientation, or by increasing the number of finance-oriented individuals on the board. But no matter how the companies increased the percentage of finance- 
Table 2

Correlations among all variables.

\begin{tabular}{|c|c|c|c|c|c|c|c|c|}
\hline & & 2 & 3 & 4 & 5 & 6 & 7 & 8 \\
\hline 1. & Company Age & $0.36^{* * *}$ & $0.37^{* * *}$ & -0.04 & -0.21 & -0.04 & 0.16 & -0.08 \\
\hline 2. & Company Size & & $0.41^{* * *}$ & 0.11 & -0.09 & -0.03 & 0.13 & -0.10 \\
\hline 3. & BOD Size & & & -0.08 & -0.18 & -0.12 & 0.18 & -0.17 \\
\hline 4. & BOD \% Outsider & & & & 0.12 & 0.03 & 0.19 & -0.06 \\
\hline 5. & BOD \% Finance & & & & & 0.01 & $-0.28^{* *}$ & -0.03 \\
\hline 6. & Past Performance & & & & & & 0.13 & -0.10 \\
\hline 7. & Extent of Fall & & & & & & & $-0.57^{* * *}$ \\
\hline 8. & Extent of Recovery & & & & & & & \\
\hline
\end{tabular}

$\mathrm{N}=81$ for all relationships.

${ }^{* * *} \mathrm{p}<0.01 ;{ }^{* *} \mathrm{p}<0.05 ;{ }^{*} \mathrm{p}<0.10$.

Table 3

Performance: Multiple regression analysis with Extent of Fall and Extent of Recovery as dependent variables.

\begin{tabular}{lll}
\hline & Extent of Fall I & Extent of Recovery II \\
\hline Age of Company & $0.070(0.559)$ & $0.019(0.852)$ \\
Size of Company & $0.003(0.983)$ & $-0.021(0.845)$ \\
Past Performance & $0.139(0.198)$ & $-0.632^{* * *}(0.000)$ \\
BOD Size & $0.139(0.261)$ & $-0.085(0.424)$ \\
BOD \% Outsiders & $0.233^{*}(034)$ & $0.083(393)$ \\
BOD \% Finance & $-0.266^{* *}(0.018)$ & $-0.227^{* *}(0.025)$ \\
Constant & -0.1 .039 & -0.227 \\
R square & 0.172 & 0.375 \\
F-value & $2.562^{* *}$ & $7.414^{* * *}$ \\
\hline
\end{tabular}

$\mathrm{N}=81$.

Standard errors in parentheses.

${ }^{* * *} \mathrm{p}<0.01 ;{ }^{* *} \mathrm{p}<0.05 ;{ }^{*} \mathrm{p}<0.10$.

Table 4

Multiple regression analysis with changes in the percentage of individuals with a finance-orientation on the BOD as the dependent variable.

\begin{tabular}{ll}
\hline Age of Company & $0.000(0.997)$ \\
\% Change BOD Size & $0.220^{*}(0.033)$ \\
Extent of Fall & $-0.106(0.412)$ \\
Extent of Recovery & $-0.130(0.293)$ \\
2008 BOD \% Individuals w/finance orientation & $(0.007)$ \\
Constant & 1.192 \\
R square & 0.282 \\
F-value & $5.895^{* * *}$ \\
\hline
\end{tabular}

$\mathrm{N}=81$.

Standard errors in parentheses.

${ }^{* * *} \mathrm{p}<0.01 ;{ }^{* *} \mathrm{p}<0.05 ;{ }^{*} \mathrm{p}<0.10$.

oriented individuals, what seems perplexing is why companies would increase the percentage of finance-oriented individuals on the BODs when such actions could be detrimental to their firm's performance.

One plausible explanation, originating from the field of consumer behavior studies, is the Blissful Ignorance Effect. This research suggests that when people know less about something, it is easier for them to create their own thoughts about a decisionwhich leads to greater satisfaction-and that once people become committed to something they want to be happy about their decision (Schiffman Leon, 1988, p. 95; Solomon, 2011, p. 318). The blissful ignorance effect has been used to explain the one-way flow of information between physicians and patients (Lupton, Donaldson, \& Lloyd, 1991), the feedback on students' performance (Bandiera, Larcinese, \& Rasul, 2015), the rationale of some supreme court decisions (Dery \& Hernandez, 2007), and the blanket statements made about sportswomen in the 19th century (Guttman, 1991).

However, in the management sciences, the majority of descriptions of ignorance simply refer to settings where there is a scarcity of knowledge (Aven \& Steen, 2010). Congleton (2005) argues that individuals and groups (including organizational leadership by assumption) may embrace policies that are less effectual at advancing their objectives-that organizational decision-makers realize that unknown parameters exist but they purposely (and blissfully) decide not to investigate anything about the issue in questioned (Congleton, 2005). In other words, 'blissful ignorance' within business settings is the purposeful avoidance of unpleasant information and/or the purposeful nonresponse of any knowledge unwantedly received.

Since Blissful Ignorance has rarely been objectively measured in business organizations (if at all), an exhaustive search for measurable constructs for Blissful Ignorance suitable for business organizations and researchers was unsuccessful. Therefore, the author(s) of this paper suggests that future studies start with the following four possible manifestations of blissful ignorance, adapted from the work by Roberts (2013), p. 1) the avoidance of knowledge that is unpleasant; 2) the nonresponse to knowledge unwantedly received; 3 ) the employment of conceptual frameworks that are crude and/or limited, and; 4) the employment of rigid preconceptions to reduce uncertainty.

Perhaps the most difficult hurdle, for researchers and practitioners, is the likely contention that 'blissful ignorance' will not exist in business organizations in such rates that would support meaningful results. While that may be the case among a sample of business organizations from a diverse number of industries, there are logical counterpoints to support the assumption that blissful ignorance would exist in meaningful amounts among companies from the same industry, such as the hospitality industry, to allow statistical significant results.

For example, while diversity and vive la différence seem to get the lion's share of researchers' scrutiny, there are still a number of driving forces aimed at increasing homogeneity or standardization across organizations, especially those in the same industry, such as the hospitality industry. For example, Fredrickson and Iaquinto (1989) found that over time, and across two very diverse industries, the companies' decision processes were becoming more rational, which they named; Creeping Rationality. The act of benchmarking, is by definition a force for homogeneity, as it is the search and assimilation of "best practices" (cf. Drew, 1997), and the same could be said about industry paradigms, which are industrywide forces for change (cf. Jauhari, 2014; Jovane, Koren, \& Boer, 2003). Therefore, while the author(s) of this study cannot conclude that 'Blissful Ignorance' is widespread-potential detractors cannot completely reject the possibility that 'Blissful Ignorance' exists in rates that would lead to meaningful results.

\section{Other observations}

Beyond our primary and ad hoc findings, there is one notable observation - that being the significant negative relationship between the extent of a company's fall and the extent of a company's 
recovery. In other words, companies that fell the furthest during a crisis had, on average, a stronger recovery. While the author(s) of this study quickly noted that result ran against the well-worn adage about digging oneself into a big hole, the most likely explanation for this finding is simply an artifact of the data, that firms that fell further had a smaller base (stock price) to build upon, the assumption being that companies can more readily increase their stock price when shares are $\$ 2 /$ share than when they are at $\$ 20$ / share.

However, there is still a possibility that something a little more compelling has been recorded. More specifically, it is quite plausible that the external environment during the frontend of a crisis is different than at the backend of a crisis. If true, then the next logical assumption would argue that inflection points exist between the frontend of a crisis and the backend (Castiglione, 2006), and those companies capable enough to recognize the environmental changes, and had the willingness and ability to act on that knowledge, were able to recover better (Burgelman \& Grove, 1996). However, Wood, Williams, and Grégoire (2012) argues that different cognitive processes are needed as business leaders travel through the different phases facing a company, as well (assumingly) in the varied stages of a crisis (Fink, Beak, \& Taddeo, 1971; Orlowski, 2008). Therefore, managers need to be able to recognize and act on these "inflection points" in order to be successful. Unfortunately, Grove and Andrew (1997) argues that is difficult for managers to distinguish a strategic inflection point from the regular hustle and bustle of daily stimuli that managers must scan, recognize and act on.

The results from this study also complements the work by Rost and Osterloh (2010) who found, among TMTs in a set of banks, a significant negative relationship between the percentage of financial experts and firm performance during the same financial crisis used as the backdrop of the current study. If these two findings are further validated, it could have significant practitioner implications, as companies may need to conduct reviews of the demographic makeup of a firm's upper echelons, more specifically the percentages of individuals with a finance orientation.

Finally, this study adds to the stream of research that examines the impact of organizational leadership on firm performance during times when companies are particularly vulnerable, such as in times of a crisis. For example Fischer and Pollock (2004) found that the average management team tenure can decrease the likelihood of organization failure within the first five months after an IPO.

\section{Future research}

Prior tests of the upper echelons perspective have used such diverse dependent variables as: CSR Rankings (Huang, 2013), ROE (Marimuthu \& Kolandaisamy, 2009), the degree a firm is internationalized (Nielsen, 2010b) and lagged variables (Colbert et al., 2014). Unfortunately, while successfully utilizing an assortment of dependent variables might be a sign of a robust theory, others have warned that the upper echelons perspective has become overly sensitive to the performance measures used (Boerner, Linkohr, \& Kiefer, 2011). Therefore, researchers interested in the impact of the demographic compositions of organizational leadership on firm performance during a crisis will need to develop more universally acceptable measures of company performance during a crisis. This study limited its measure to the extent of a company's fall and recovery. However, investigating the speed of a company's fall (or recovery) and the efficiency and/or effectiveness of its recovery (if not a composite measure) should be of interest to researchers and managers alike. In 2012, W.T. Wang proposed a framework for measuring organizational performance during a crisis However, outside of case studies, Wang's framework seems rather unwieldy for empirical studies.

There is also a need to examine differences in crisis management across cultures, industries, generations and functional areas, which would help address the internal and external validity of the current results. For example, Fowler et al. (2007) found that upper and middle managers were more aware of a company's crisis preparedness than employees.

This study look at just one kind of crisis, these results could differ depending, for example, on the complexity of the crisis (Mitroff \& Alpaslan, 2003; Pandelica \& Pandelica, 2009, pp. 311-324). Furthermore, researchers should be encouraged to investigate variables that might moderate the link between the demographic characteristics of organizational leadership and firm performance during a crisis, such as organizational slack (cf. Boerner et al., 2011; Wu, Zelong, \& Qiaozhuan, 2011).

Finally, this study assumed that investor actions were the result of signals, real or perceived. Therefore, future research should seek to uncover those specific signals that most influence perceptions among market participants in a time of crisis. And finally, this study acknowledges the continued need to examine the 'black box' that may provide the operative mechanism linking leadership characteristics and firm performance (Tihanyi, Ellstrand, Daily, \& Dalton, 2000).

\section{Conclusion}

By providing evidence that demographic characteristics of a company's BODs can impact firm performance during a time of crisis, the current study further validates the upper echelons perspective (Hambrick, 2007; Hambrick \& Mason, 1984) and to some extent, Smits and Ezzat's (2003) framework for crisis management. For practitioners, the findings in this paper suggest that organizations in the hospitality industry should be judicious when drawing up their crisis management plans by including instructions on how to manage the demographic characteristics of the firm's upper echelons. Finally, the paper suggests that within the upper echelons of the hospitality industry, there may individuals that display actions consistent with decision makers that are under the influence of a managerial variant of the blissful ignorance effect.

\section{References}

Adams, R. B., deHaan, J., Terjesen, S., \& vanEes, H. (2015). Board diversity: Moving the field forward. Corporate Governance, 23, 77-82.

Alexiev, A. S., Jansen, J., Van den Bosch, F. A., \& Volberda, H. W. (2010). Top management team advice seeking and exploratory innovation: The moderating role of TMT heterogeneity. Journal of Management Studies, 47, 1343-1364.

Aven, T., \& Steen, R. (2010). The Concept of ignorance in a risk assessment and risk management context. Reliabity Engineering \& System Safety, 95(11), 1117-1122.

Bamber, L. S., Jiang, J., \& Wang, I. Y. (2010). What's my style? The influence of top managers on voluntary corporate financial disclosure. The Accounting Review, 85(4), 1131-1162.

Bandiera, O., Larcinese, V., \& Rasul, I. (2015). A natural experiment on the effect of feedback on students' performance. Labour Economics, 34, 13-25.

Becchettie, L., Ceniccola, C. \& Ciciretti, R. (2010). Stock market reaction to the global financial crisis: The role of corporate governance and product quality ratings in the Lehman Brothers' event. In Proceedings of the 2010 MISTRA workshop on sustainable investment. University of Leicester School of Management.

Boerner, S., Linkohr, M., \& Kiefer, S. (2011). Top management team diversity: Positive in the short run, but negative in the long run? Team Performance Management: An International Journal, 17(7/8), 328-353.

Brandstrum, A., Bynander, F., \& Hart, P. (2004). Governing by looking back: Historical analogies and crisis management. Public Adminstration, 82, 191-210.

Brochet, F., \& Welch, K. T. (2011). Top executive background and financial reporting choice, harvard business school research paper No. 1765928. Available at SSRN http://ssrn.com/abstract=1765928.

Burgelman, R. A., \& Grove, A. S. (1996). Strategic dissonance. California Management Review, 38(2), 8-28.

Castiglione, J. (2006). Organizational learning and transformational leadership in the library environment. Library Management, 27(4/5), 289-299.

Chavan, M. (2005). An appraisal of environment management systems: A competitive advantage for small businesses. Management of Environmental 
Quality: An International Journal, 16(5), 444-463.

Chava, S., \& Purnanandam, A. (2010). Is default risk negatively related to stock returns? Review of Financial Studies, 107.

Cho, T. S., \& Hambrick, D. C. (2006). Attention as the mediator between top management team characteristics and strategic change: The case of airline deregulations. Organization Science, 17(4), 453-469.

Colbert, A. E., Barrick, M. R., \& Bradley, B. H. (2014). Personality and leadership composition in top management teams: Implications for organizational effectiveness. Personnel Psychology, 67, 351-387.

Congleton, R. D. (2005). Toward a political economy of crisis management: Rational choices, ignorance, and haste in political decision making. Advances in Austrian Economics, 8.

Dery, G., \& Hernandez, M. (2007). Blissful Ignorance? The supreme court's signal to police in Georgia versus Randolph. Connecticut Law Review, 40(1), 53-65.

Drew, S. A. W. (1997). From knowledge to action: The impact of benchmarking on organizational performance. Long Range Planning, 30(3), 427-441.

Eesley, C. E., Hsu, D. H., \& Roberts, E. B. (2014). The contingent effects of top management teams on venture Performance: Aligning founding team composition with innovation strategy and commercialization environment. Strategic Management Journal, 35, 1798-1817.

Eisenhardt, K. M., \& Schoonhoven, C. B. (1990). Organizational growth: Linking founding team, strategy, environment, and growth among U.S. semiconductor ventures, 1978-1988. Administrative Science Quarterly, 35, 504-529.

Ferrero-Ferrero, I., Fernandez-Izquierdo, M., \& Munoz-Torres, M. J. (2015). Corporate social responsibility and environmental management. Journal of Organizational Change Management, 26(5), 193-207.

Fink, S. L., Beak, J., \& Taddeo, K. (1971). Organizational crisis and change. The Journal of Applied Behavioral Science, 7(1), 15-37.

Fischer, H., \& Pollock, T. (2004). Effects of social capital and power on surviving transformational change: The case of initial public offerings. Academy of Management Journal., 47(4), 463-481.

Fowler, K., Kling, N. D., \& Larson, M. D. (2007). Organizational preparedness for coping with a major crisis or disaster. Business \& Society, 46(1), 88-103.

Fredrickson, J. W., \& Iaquinto, A. L. (1989). Inertia and creeping rationality in strategic decision processes. Academy of Management Journal, 32, 516-542.

Geletkanycz, M. A., \& Hambrick, D. C. (1997). The external ties of top executives: Implications for strategic choice and performance. Administrative Science Quarterly, 42(4), 664-681.

Goldberg, A., \& Petasnick, W. (2010). Managing in a downturn: How do you manage in a global financial Recession? Journal of Healthcare Management, 55(3), 149-153.

Goodman, J., O'Brien, P., \& Segal, E. (2000). Turning CFOs into quality champions. Quality Progress, 33(3), 47-54.

Grove, D., \& Andrew, S. (1997). Navigating strategic inflection points. Business Strategy Review, 8(3), 11-18.

Guttman, A. (1991). Woman's sports: Analysis of women's participation in sports. New York: NY: Columbia University Press.

Hambrick, D. C. (2007). Upper echelons Theory: An update. Academy of Management Review, 32(2), 334-343.

Hambrick, D. C., \& Mason, P. A. (1984). Upper echelons: The organization as a reflection of its top management. Academy of Management Review, 9, 193-206.

Hannan, M. T., \& Freeman, J. (1984). Structural inertia and organizational change. American Sociological Review, 49(2), 149-164.

Higgins, M. C., \& Gulati, R. (2005). Stacking the deck: The effects of top management backgrounds on investor decisions. Strategic Management Journal, 27(1), 1-25.

Homberg, F., \& Hong, T. M. (2013). Top management team diversity: A systematic review. Group Organization Management, 38(4), 455-479.

Hsu, W. T., Chen, H.-L., \& Cheng, C. Y. (2013). Internationalization and firm performance of SMEs: The moderating effects of CEO attributes. Journal of World Business, 48(1), 1-12.

Huang, S. K. (2013). The impact of CEO characteristics on corporate sustainable development. Corporate Social Responsibility Environment Management, 20, 234-244.

Jauhari, V. (2014). Sustainability programs in the hospitality industry. Oakville, Canada: Apple Academic Press.

Jovane, F., Koren, Y., \& Boer, C. R. (2003). Present and future of flexible automation: Towards new paradigms. CIRP Annals - Manufacuring Technology, 52(2), $543-560$.

Karasek, R., \& Bryant, P. (2012). Signaling theory: Past, present, and future. Academy of Management Journal, 11(1), 91-99.

Lawson, B., \& Omer, T. (2012). Beyond the CFO and accrual decisions: An Examination of individual audit committee chairs, CEOS, and CFOs and their Influence on reporting and operating decisions. Available at SSRN http://ssrn.com/ abstract $=2218484$.

Lehn, K., \& Makhija, A. K. (1996). As performance measures and signals for strategic change. Strategy and Leadership, 24(3), 34-38.

Li, C.-R. (2013). How top management team diversity fosters organizational ambidexterity : The role of social capital among top executives. Journal of Organizational Change Management, 26(5), 874-896.

Lupton, D., Donaldson, C., \& Lloyd, P. (1991). Caveat emptor or blissful ignorance? Patients and the consumerist ethos. Social Science and Medicine, 33(5), 559-568.
Marcus, A. A., \& Goodman, R. S. (1991). Victims and shareholders: The dilemmas of presenting corporate policy during a crisis. Academy of Management Journal, 34(2), 281-305.

Marimuthu, M., \& Kolandaisamy, I. (2009). Demographic diversity in top level management and its implications on firm financial performance: An empirical discussion. International Journal of Business and Management, 4(6), 176.

Merchant, K. A., \& Bruns, W. J., Jr. (1986). Measurements to cure management myopia. Business Horizons, 29(3), 56-64.

Michel, J. G., \& Hambrick, D. C. (1992). Diversification posture and top management characteristics. Academy Management Journal, 35, 9-37.

Minton, B. A., Taillard, J., \& Rohan. (2011). Do independence and financial expertise of the board matter for risk taking and performance? (February 15, 2011). Available at SSRN https://ssrn.com/abstract $=1787126$.

Mitroff, I., \& Alpaslan, M. C. (2003). Preparing for evil. Harvard Business Review, 81(4), 109-115.

Murray, A. I. (1989). Top management group heterogeneity and firm performance. Strategic Management Journal, 10, 125-141.

Nielsen, S. (2010a). Top anagement team diversity: A review of theories and methodologies. International Journal of Management Reviews, 12, 301-316.

Nielsen, S. (2010b). Top management team internationalization and firm performance. Management International Review, 50(2), 185-206.

Nielsen, B. B., \& Nielsen, S. (2013). Top management team nationality diversity and firm performance: A multilevel study. Strategic Management Journal, 34, $373-382$

Ocasio, W. (1997). Towards an attention-based view of the firm. Strategic Management Journal, 18, 187-206.

Orlowski, L. T. (2008). Stages of the 2007/2008 global financial crisis is there a wandering asset-price bubble? Economics discussion paper No. 2008-43. Available at SSRN http://ssrn.com/abstract=1726700.

Pandelica, I., \& Pandelica, A. (2009). Additional thoughts on the response of the organizations in crisis conditions. In The proceedings of the international conference. Babes Bolyai University.

Pearson, C., \& Clair, J. A. (1998). Reframing crisis management. Academy of Management Review, 23(10), 59-76.

Post, C., \& Byron, K. (2015). Women on boards and firm financial performance: A meta-analysis. Academy of Management Journal, 58(5), 1546-1571.

Ritchie, B. W. (2004). Chaos, crises and disasters: A strategic approach to crisis management in the tourism industry. 25(6), 669-683.

Rivas, J. L. (2012). Diversity and internationalization: The case of boards and TMTs. International Business Review, 21(1), 1-12.

Roberts, J. (2013). Organizational ignorance: Towards a managerial perspective on the unknown. Management Learning, 44(3), 215-236.

Rost, K., \& Osterloh, M. (2010). Opening the black box of upper echelons: Drivers of poor information processing during the financial crisis. Corporate Governance: An International Review, 18, 212-233.

Schiffman Leon, G. (1988). Consumer behavior. Prentice Hall of India. ISBN 978-81317-3156-7.

Smart, C., \& Vertinsky, I. (1984). Strategy and the environment: A study of corporate responses to crises. Strategic Management Journal, 5(3), 199-213.

Smith, K. G., Smith, K. A., Olian, J. D., Sims, H. P., Jr., O'Bannon, D. P., \& Scully, J. A. (1994). Top management team demography and process: The role of social integration and communication. Administrative Science Quarterly, 39, 412-438.

Smits, S., \& Ezzat, N. (2003). Thinking the unthinkable; leadership's role in creating behavioral readiness for crisis management. Competitiveness Review, 13(1), $1-23$.

Solomon, M. (2011). Consumer behavior. Upper Saddle River, New Jersey: Pearson Education. ISBN 978-0-13-611092-7.

Spence, M. (1973). Job market signaling. Quarterly Journal of Economics, 87(3), 355-374.

Talkea, K., Salomob, S., \& Rost, K. (2010). How top management team diversity affects innovativeness and performance via the strategic choice to focus on innovation fields. Research Policy, 39(7), 907-918.

Terjesen, S., Couto, E. B., \& Francisco, P. M. (2016). Does the presence of independent and female directors impact firm performance? A multi-country study of board diversity. Journal of Management \& Governance, 20(3), 447-483.

Tihanyi, L., Ellstrand, A., Daily, C., \& Dalton, D. (2000). Composition of the top management team and firm international diversification. Journal of Management, 26(6), 1157-1177.

Tuggle, C., Schnatterly, S. K., \& Johnson, R. (2010). Attention patterns in the boardroom: How board composition and processes affect discussion of entrepreneurial issues. Academy of Management Journal, 53(3), 550-571.

Wang, W. T. (2012). Evaluating organizational performance during crises: A multidimensional framework. Total Quality Management \& Business Excellence, 23(5/ 6), 673-688.

Wood, M. S., Williams, D. W., \& Grégoire, D. A. (2012). The road to riches? A model of the cognitive processes and inflection points underpinning entrepreneurial action. Advances in Entrepreneurship, Firm Emergence and Growth, 14, 207-252.

Wu, Y., Zelong, W., \& Qiaozhuan, L. (2011). Top management team diversity and strategic change: The moderating effects of pay imparity and organization slack. Journal of Organizational Change Management, 24(3), 267-281.

Zack, M. H. (1999). Developing a knowledge strategy. California Management Review, 41(3), 125-145. 
Finance-oriented directors and crisis management: Blissful ignorance in the hospitality industry?

Macpherson, WG

2017-05-24

http://hdl.handle.net/10179/15337

22/04/2023 - Downloaded from MASSEY RESEARCH ONLINE 